\title{
Influence of Protein Malnutrition on Prenatal Toxicity of Fluoxetine
}

\author{
*Hamed M.R.; *Asmaa M. Kandil; ** El shorbagy O. and *Zeinab M. A. Abbas \\ * National Organization for Drug Control and Research **Institute of Postgraduate \\ childhood studies. Ain Shams University
}

\begin{abstract}
Background: Protein malnutrition is prevalent in developing countries. Gestational and neonatal malnutrition were considered to contribute to the development of chronic diseases in adulthood.

The aim of the present work was to investigate the influence of prenatal protein malnutrition on embryo -fetal toxic effects of the commonly used antidepressant drug Fluoxetine.

Methods: The pregnant rats were divided into two sets: normally fed and protein malnourished. Each set was sub- divided into five groups of 10-14 animals each. Starting from 1st day of pregnancy, animals were fed with standard diet (20\% casein). Animals specified for protein malnutrition were switched to protein deficient diet (8\%casein) from the 7th day of gestation throughout the end of pregnancy. Fluoxetine hydrochloride was administrated orally in the dose levels $2 \mathrm{mg}$ and $8 \mathrm{mg} / \mathrm{kg} /$ day from day 7 to 14 and from day 15 to 20 of gestation. At the $20^{\text {th }}$ day of gestation the outcome of pregnancy was examined immediately for viability and fetal growth parameters, placental weight as well as fetal external anomalies. Hb, RBCs count, total and differential WBCs and platelets counts were estimated. Fetuses from each group were subjected to skeletal examinations using the Alcian blue and Alizarin red technique.

Result:The results showed that prenatal protein malnutrition and administration of Fluoxetine in the high used dose level $8 \mathrm{mg} / \mathrm{kg}$ were found to cause significant decrease in fetal growth parameters, and placental weights increase in resorption of fetuses multiple hematomas.

Blood examination of protein malnourished fetuses and groups treated with fluoxetine revealed significant decrease in $\mathrm{Hb}$ level; RBCs count \& platelets, however, total the leucocytic count was increase. The incidence of skeletal abnormalities was more obvious when fluoxetine was administrated during embryogenesis period.
\end{abstract}

Key words: Protein Malnutrition, Prenatal, Fluoxetine

\section{Introduction}

Malnutrition occurring during intrauterine period and the first two years of life has adverse effects on child survival and development. When Women in poor areas become pregnant, their nutritional state frequently worsens as the additional demands of pregnancy are not met (De Onis et al., 1998).

Alterations in fetal nutrition and endocrine status may result in developmental adaptations that permanently change the structure, physiology and metabolism of the offspring, thereby predisposing individuals to metabolic, endocrine and cardiovascular diseases in adult life (Barker, 1994).Malnutrition may affect the rate of development by causing premature cessation of cell division and early cell differentiation (Cunningham et al., 1997;

Hamed et al., 1998; Harding, 2001; Kramer, 2002 and Villar et al., 2003).

The major components of infant mortality i.e. prenatal and early neonatal mortality are directly related to the health and nutritional status of the mother during pregnancy. In developing countries, intrauterine growth retardation (IUGR) is an important determinant of Prenatal mortality. Morbidity is also increased in low birth weight newborns.

$50 \%$ of all low birth weight babies in Egypt can beattributed to IUGR. A negative correlation between neonatal mortality and birth weight was reported (Mansour et al., 1998; LBWSE, 2000).In animals, nutritional deficiency of protein does not cause congenital defects, but can increase prevalence of stillbirth and abortions (Kotera and Madigan, 1997).

Severe degrees of protein deprivation and vitamin deficiencies in mice lead to fetal and placental resorption (Hamed et al.,1994).

Prenatal protein malnutrition in rats may delay the change of proteoglycan character which could affect mineralization of fetal bones (Miwa et al $1989 \&$ 1990). 
Chronic protein malnutrition in humans has a profound detrimental effect on fracture healing (Day and Deheer, 2001).

In a study by Barone et al. (1998), they found that low protein diet $(4 \%)$ in pregnant rat during the second half of

gestation alters copper and iron transport across the placenta and affects copper and iron status of the fetus leading to fetal anemia and hypoproteinemia .

Protein- calorie malnutrition alters drug disposition and its metabolism in human and in animal models (Anderson, 1988). Protein malnutrition was shown to antagonize the behavioral response to chlorpromazine, increases the sensitivity to amphetamine (Hamed et al., 1991) and potentiates the embryo lethal effects of aspirin in rats (Hamed et al., 1994).

This work aims to investigate the influence of prenatal protein malnutrition on embryo-fetal toxic effects of Fluoxetine.

\section{Material and Methods}

Animals 122 Pregnant Sprague Dawley rats were obtained from the animal house of NODCAR. Two females were placed into the cage of one male overnight and presence of sperm in vaginal smears considered the zero day of pregnancy. Mated females were carried and housed in a room maintained at a temperature of $23 \pm 3{ }^{\circ} \mathrm{C}$ and a relative humidity of $50 \% \pm 10 \%$.

Experimental Design: Standard diet contains $20 \%$ casein was given to rats from the first day of gestation (Bamji \& Sharada, 1972 and Anthony \&Edozien, 1975). The low protein diet (containing 8\% casein) was composed of the same constituents of the standard diet except that the amount of casein was reduced to $8 \mathrm{~g}$ and of sucrose raised to $82 \mathrm{~g} / 100 \mathrm{~g}$ food.Animals of each main group were sub divided into $10 \mathrm{sub}$ groups as follows:

Sub group C1: normal untreated group where animals were fed normal diet (normal fed NF).

Sub group C2: normal untreated group where animals were fed protein malnourished diet

Sub group E1: animals were administered daily $2 \mathrm{mg} / \mathrm{kg}$ fluoxetine hydrochloride orally from the 7 th to the 14th day of gestation and were fed normal protein diet ( $20 \%$ casein).

Sub group E2: animals were administered daily $2 \mathrm{mg} / \mathrm{kg}$ fluoxetine hydrochloride orally from the 7 th to the 14th day of gestation and were fed protein malnourished diet ( $8 \%$ casein).

Sub group E3: animals were administered daily $8 \mathrm{mg} / \mathrm{kg}$ fluoxetine hydrochloride orally from the 7 th to the 14th day of gestation and were fed normal protein diet ( $20 \%$ casein).

Sub group E4: animals were administered daily $8 \mathrm{mg} / \mathrm{kg}$ fluoxetine hydrochloride orally from the
7 th to the 14th day of gestation and were fed protein malnourished diet ( $8 \%$ casein).

Sub group E5: animals were administered daily $2 \mathrm{mg} / \mathrm{kg}$ fluoxetine hydrochloride orally from the 15 th to the 20th day of gestation and were fed normal protein diet (20\% casein).

Sub group E6: animals were administered daily $2 \mathrm{mg} / \mathrm{kg}$ fluoxetine hydrochloride orally from the15th to the 20th day of gestation and were fed protein malnourished diet ( $8 \%$ casein).

Sub group E7: animals were administered daily $8 \mathrm{mg} / \mathrm{kg}$ fluoxetine hydrochloride orally from the 15 th to the 20th day of gestation while animals were fed normal protein diet (20\% casein).

Sub group E8: animals were administered daily $8 \mathrm{mg} / \mathrm{kg}$ fluoxetine hydrochloride orally from the 15 th to the 20th day of gestation while animals were fed protein malnourished diet ( $8 \%$ casein). At the day 20 st of gestation fetuses were removed from the uteri of pregnant rats by cesarean section and number of implantations, resorptions, placental weights ( $\mathrm{g}$ ) and viability of fetuses were recorded.

Fetal growth parameters: body weight (g), crown- rump length $(\mathrm{cm})$, and tail length $(\mathrm{cm})$ were measured. Fetal external examinations and skeletal examinations were done according to the methods of Mcleod, (1980). Hematological parameters of fetuses including hemoglobin level( $\mathrm{Hb}$ ), erythrocytic count (RBCs), total and differential leucocytic count(TLC) and platelets count were measured.

according to Taylor and Miler method, 1965 England et al (1976), Nourbakhsh et al, (1978), Hayahoe and Flemans (1982) and Wertz and Koepke (1977) respectively.

Statistical methods: Comparisons between categorical variables were done by the chisquare test (Dawson and Trapp, 2001). All pvalues are two sided. P-Values $<0.05$ were considered significant.

\section{Results}

No major external abnormalities were detected in the fetuses whether of protein malnourished or normally fed treated rats

Effects of fluoxetine and malnutrition on pregnancy

Table 1 showed that the groups of protein malnourished pregnant rats have higher percentage of abortion (36.7\%) in comparison to those of normally fed pregnant rats $(29 \%)$, but the difference between the two groups was statistically insignificant (P-value=0.369). However the highest percentage of abortion $(50 \%)$ was showed in group administered fluoxetine $8 \mathrm{mg} / \mathrm{kg}$ daily during the 7 th to the 14 th days of gestation.

Effects of fluoxetine and malnutrition on the fetuses There are no stillbirths have been 
recorded in all groups. However resorbed fetuses were observed in normally fed and protein malnourished groups. The percentage of resorption in normally fed groups was $3.9 \%$ while in protein malnourished groups it was 8.6\% (Table 1 and Figs.1\&2). The increased rate of resorption among protein malnourished groups compared to normally fed groups was considered statistically significant (P-value = 0.032). However, the highest percentage of resorption $(14.3 \%)$ was recorded in the group of protein malnourished and treated with fluoxetine $8 \mathrm{mg} / \mathrm{kg}$ daily during the 7 th to the 14th days of gestation.

External anomalies: Hematomas of variable extent were detected in all treated groups as shown in table 1 and figure 3 . Unilateral fore-or hind-limb hematoma was a common observation. Other sites of hematomas were observed at circumsolar region, tip of tail and abdominal wall. Hematomas could be detected in the same fetus in different sites. Severity of hematoma could lead to falling of toes, as noticed in some fetuses of groups (E4) and (E6) in which the percentages of hematomas were $72 \%$ and $62.5 \%$, respectively.

Statistical significant difference was observed between normally fed andprotein malnourished groups (P-value<0.001). Fetal growth: Fetal body weights (FBW), fetal crown-rump lengths (FCRL), tail lengths and placental weights are significantly decreased in protein malnourished groups in comparison to normally nourished groups (Table 2 and Fig. 3).

Daily oral administration of fluoxetine, to pregnant normally fed rats in doses $2 \mathrm{mg}$ and $8 \mathrm{mg} / \mathrm{kg}$ during embryogenesis and fetogenesis, produced insignificant differences in FBW, FCR, tail lengths and placental weight compared to normal control. The decrease in FBW observed in control $(3.34 \pm 0.43 \mathrm{~g})$ and treated malnourished groups (3.32 \pm 0.55 , $3.35 \pm 0.38, \quad 3.25 \pm 0.34$ and $3.09 \pm 0.55 \mathrm{~g})$ was considered statistically significant as compared to normal control $(3.77 \pm 0.59 \mathrm{~g})$. Administration of fluoxetine to protein malnourished pregnant rats in a daily dose of $8 \mathrm{mg} / \mathrm{kg}$ from the 15 thto the 20th days of gestation, result in the most affection of mean FBW $(3.09 \pm 0.55 \mathrm{~g})$. No statistical significance differences in the fetal body weights were observed in treated protein malnourished rats between drug doses in different gestational periods.

Fetal crown - rump length (FCRL):Table 2 showed that the control group in normally fed rats (C1) had fetuses with mean crown-rump length of $3.96 \pm 0.23 \mathrm{~cm}$. Oral administration of fluoxetine daily in $2 \mathrm{mg} / \mathrm{kg}$ whether in embryogenesis or fetogenesis periods produced insignificant decrease in FCRL as compared to normal control. While groups E7\&F8 $(8 \mathrm{mg} / \mathrm{kg})$ has significantly decreased FCRL.

In protein malnourished groups, oral administration of fluoxetine daily during the 7 th to the 14th days of gestation in doses of $2 \mathrm{mg}$ and $8 \mathrm{mg} / \mathrm{kg}$ produced significant decrease in FCRL as compared to control malnourished group. Oral administration of fluoxetine daily during the 15 th to the 20th days of gestation in $2 \mathrm{mg} / \mathrm{kg}$ produced insignificant decrease in FCRL while significant decrease was observed in $8 \mathrm{mg} / \mathrm{kg}$ as compared to control malnourished group.

The above observations showed that $8 \mathrm{mg} / \mathrm{kg}$ of fluoxetine administered in both gestational periods in N.F and P.M groups caused significant decrement in fetal crown-rump lengths. Dose of $2 \mathrm{mg} / \mathrm{kg}$ during the 7 th to the 14th days of gestation caused significant de-crease in FCRL only in protein malnourished groups.

Fetal tail length (FTL):Oral administration of fluoxetine daily from the 7 th to the 14th days of gestation in $2 \mathrm{mg} / \mathrm{kg}$ produced insignificant.

decrease in FTL compared to normal control, while the $8 \mathrm{mg} / \mathrm{kg}$ dose produced significant decrease in FTL. Administration of fluoxetine daily from the 15 th to the 20th days of gestation in both doses produced significant decrease in fetal tail lengths compared to normal control (Table 2).

In protein malnourished rats, admini-stration of fluoxetine daily from the 7 th to the 14 th days of gestation in a dose of $2 \mathrm{mg} / \mathrm{kg}$ produced insignificant decrease in FTL compared to control malnourished group while a dose of $8 \mathrm{mg} / \mathrm{kg}$ produced significant decrease. Administration of fluoxetine daily from the 15th to the 20th days of gestation in doses of $2 \mathrm{mg}$ and $8 \mathrm{mg} / \mathrm{kg}$ produced significant decrease in fetal tail length compared to control malnourished group.

Placental weight: Oral administration of fluoxetine daily from the 7 th to the 14th days of gestation in $2 \mathrm{mg} / \mathrm{kg}$ produced insignificant decrease in placental weight compared to control normally fed group, meanwhile the $8 \mathrm{mg} / \mathrm{kg}$ dose produced significant decrease (Table 2).

Administration of fluoxetine daily from the 15th to the 20th days of gestation in $2 \mathrm{mg} / \mathrm{kg}$ produced significant decrease in placental weight compared to normally fed control while $8 \mathrm{mg} / \mathrm{kg}$ induced decrease but statistically insignificant. The control group of protein malnourished rats had mean placental weight of $0.52 \pm 0.05 \mathrm{~g}$ which was considered significantly lower than control normally fed $(0.59 \pm 0.07 \mathrm{~g})$. Administration of fluoxetine daily from the 7 th to the 14th days of gestation in the doses of $2 \mathrm{mg}$ and $8 \mathrm{mg} / \mathrm{kg}$ produced insignificant decrease in 
placental weight compared to control malnourished. During fetogenesis period (15th20thday) only the dose of $8 \mathrm{mg} / \mathrm{kg}$ that produced significant decrease in placental weight.

Hematological parameters: Fetal $\mathrm{Hb}$ concentration:Table 3 showed that $\mathrm{Hb}$ conc-entration and RBCs count were signify-cantly lower in fetuses of all groups of protein malnourished (P.M) pregnant rats compared to those of normally fed (N.F). Mean $\mathrm{Hb}$ concentration in fetuses of control normally fed mothers (N.F) were $14.9 \mathrm{~g} \%$. Mean $\mathrm{Hb}$ concentration. in the control P.M fetuses were $11.4 \pm 0.8 \mathrm{~g} \%$.

On administration of fluoxetine in the dose of 2 $\mathrm{mg} / \mathrm{kg}$ daily during the 7 th to the 14 th days of gestation in NF and PM rats, the mean fetal $\mathrm{Hb}$ concentration was $14.3 \pm 1.2 \& 10.8 \pm 1.4$ respectively. Significant decrease in mean fetal $\mathrm{Hb}$ concentration occurred on administration of the dose of $8 \mathrm{mg} / \mathrm{kg}$ during the same gestational period in NF and PM rats $(13.6 \pm 1 \& 9.6 \pm 1.9$ respectively) in comparison to controls.

On administration of fluoxetine in $2 \mathrm{mg} / \mathrm{kg}$ daily during the 15 th to the 20th days of gestation in N.F and P.M rats, the mean fetal $\mathrm{Hb}$ concentration were $14.6 \pm 1 \& 10.6 \pm 2$ respectively meanwhile with the $8 \mathrm{mg} / \mathrm{kg}$ dose the mean fetal $\mathrm{Hb}$ concentration was $14 \pm$ 0.8.No significant decrease in fetal $\mathrm{Hb}$ concentration was observed on administration of fluoxetine in doses of $2 \mathrm{mg} / \mathrm{kg}$ during the 15th to the 20th days of gestation in N.F and P.M rats in comparison to controls $14.6 \pm 1 \& 10.6 \pm 2$ respectively while with the $8 \mathrm{mg} / \mathrm{kg}$ dose the mean fetal $\mathrm{Hb}$ conc. was $14 \pm 0.8$ and $10.2 \pm 0.8$ respectively.

Fetal RBCs count: Table 3 showed that RBCs count were significantly lower in fetuses of all groups of protein malno-urished (PM) pregnant rats compared to those of normally fed (N.F). Mean RBCs counts in fetuses of control normally fed mothers (N.F) was 7.83.Mean RBCs count in the control P.M fetuses was 5.20 \pm 0.6 .

On administration of fluoxetine in the dose of 2 $\mathrm{mg} / \mathrm{kg}$ daily during the 7 th to the 14 th days of gestation in NF and PM rats, the mean fetal RBCs counts were $6.43 \pm 1.32 \& 3.94 \pm 0.47$ respectively. Significant decrease in mean fetal RBCs counts occurred on administration of the dose of $8 \mathrm{mg} / \mathrm{kg}$ during the same gestational period in N.F and P.M rats $(5.73 \pm 1.25 \& 3.82 \pm$ 0.34 respectively) in comparison to controls. On administration of fluoxetine in $2 \mathrm{mg} / \mathrm{kg}$ daily during the $15^{\text {th }}$ to the $20^{\text {th }}$ days of gestation in N.F and P.M rats, the mean fetal Hb conc. \& RBCs counts were $14.6 \pm 1 \& 10.6$ \pm 2 and $6.76 \pm 0.56 \& 4.39 \pm 0.51$ respectively meanwhile with the $8 \mathrm{mg} / \mathrm{kg}$ dose the mean fetal $\mathrm{Hb}$ conc. was $14 \pm 0.8$ and 10.2 \pm 0.8 respectively.

There was significant decrease in mean fetal RBCs counts in groups treated with fluoxetine in doses of 2 or $8 \mathrm{mg} / \mathrm{kg}$ during the $15^{\text {th }}$ to the $20^{\text {th }}$ days of gestation in N.F and P.M rats in comparison to controls $6.76 \pm 0.56 \& 4.39 \pm$ 0.51 and $6.98 \pm 0.46 \& 3.62 \pm 0.42$ respectively Fetal platelets count: Table 3 showed that mean fetal platelets count was significantly diminished in protein malnourished groups $(435 \pm 131)$ in comparison to normally fed groups $(654 \pm 173)$. A significant decrease in mean fetal platelets count was associated with daily administration of fluoxetine in $8 \mathrm{mg} / \mathrm{kg}$ during the $15^{\text {th }}$ to the $20^{\text {th }}$ days of gestation in both normally fed $(477 \pm 110)$ and protein malnourished groups (388 $\pm 115)$.

Fetal total and differential leucocytic

Counts (TLC):

Table 3 showed that mean fetal total leucocytic count (TLC) was higher in protein malnourished groups $(12.4 \pm 4.4)$ in comparison to normally fed groups (10.2 \pm 2.7).

The mean fetal TLC was very high in protein malnourished groups treated with fluoxetine in comparison to normally fed groups except in a dose of $8 \mathrm{mg} / \mathrm{kg}$ daily at the $15^{\text {th }}$ to the $20^{\text {th }}$ days of gestation.

The increase of total leucocytic counts was associated with an increase of lymphocytes\% and proportional dec-rease of neutrophils $\%$.

Fetal skeletal system:Fetal skeletal abnormalities were most obvious in fetuses maternally treated during the $7^{\text {th }}-14^{\text {th }}$ day of gestation as shown in Table 4 and figures $4 \& 5$. The skeletal defects observed in fetuses included lack of ossification of skull bones, sternum, ribs, vertebrae, fore limbs bones ,pelvic and hind limbs bones(Fig. 5B).

The major skeletal defects were observed mainly in pelvic and hind limbs bones in theform of shortness and partial ossification of ilium ischium, pubis, femur, tibia and fibula (Fig.4 B). Tortuosity and shortness of the 13th rib were observed in some fetuses (Figs. 4B \&5 A \& B). Incomplete ossifyications of vertebral col-umn were observed mainly in sacral and caudal vertebrae (Fig 5 B). Forelimbs bones were less affected than hind limbs bones. Abnormalities detectedin forelimbs bones were in the form of partial ossifications of humerus, ulna, and radius and missed ossifications of metacarpals and phalanges (Fig.5).

in almost groups was observed in (Fig.5).

The most affected group was the group of 
fetuses of protein malnourished pregnant rats that are administered fluoxetine in a dose of $8 \mathrm{mg} / \mathrm{kg}$ during the 7 th to the 14 th days of gestation. The bone defects observed were mainly partial ossifications of hind limbs bones in $90 \%$ of fetuses, which are extended to the forelimbs in $50 \%$ of them (Fig 4B). The least effects on bones were observed in fetuses maternallyexposed to fluoxetine $(8 \mathrm{mg} / \mathrm{kg})$

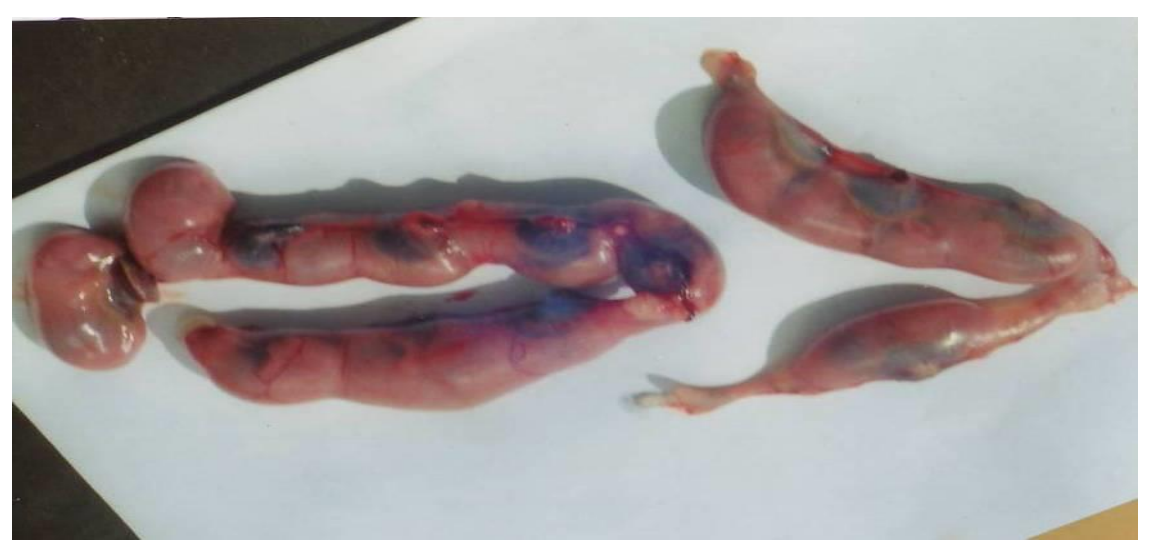

Fig (1): A photograph of two uteri of pregnant rats at the $21^{\text {st }}$ day of gestation showing: A) Normal symmetrical uterine horns of a control N.F pregnant rat.

B) Asymmetrical uterine horns of a N.F pregnant rat treated with $8 \mathrm{mg} / \mathrm{kg}$ of fluoxetine at (7-14 days) of gestation.

Fig (2): A photograph of uteri of two P.M. pregnant rats at the $21^{\text {st }}$ day of gestation treated with $8 \mathrm{mg} / \mathrm{kg}$ of Fluoxetine at (7-14 days) of gestation showing: A) Hemorrhagic spots denoting abortion. B)Complete resorption of fetuses. 


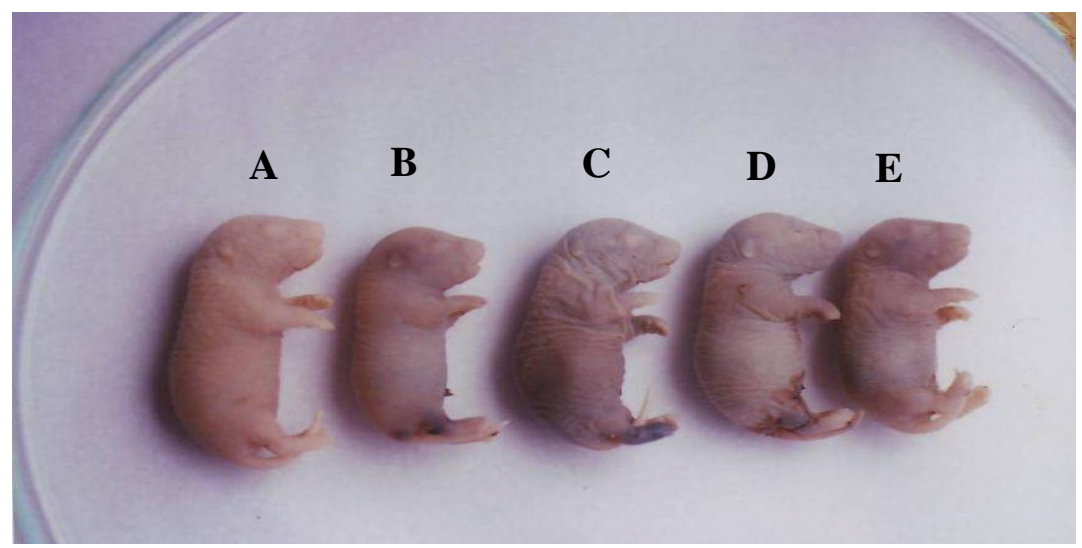

Fig (3): A photograph of fetuses at the $20^{\text {th }}$ day of gestation showing that

(A) control malnourished fetus,

(B, C\& D, E) protein malnourished fluoxetine treated fetuses by 2 and $8 \mathrm{mg} / \mathrm{kg}$ during embryogenesis and fetogenesis, respectively, showing multiple hemorrhagic sites with variable degrees of severitv.
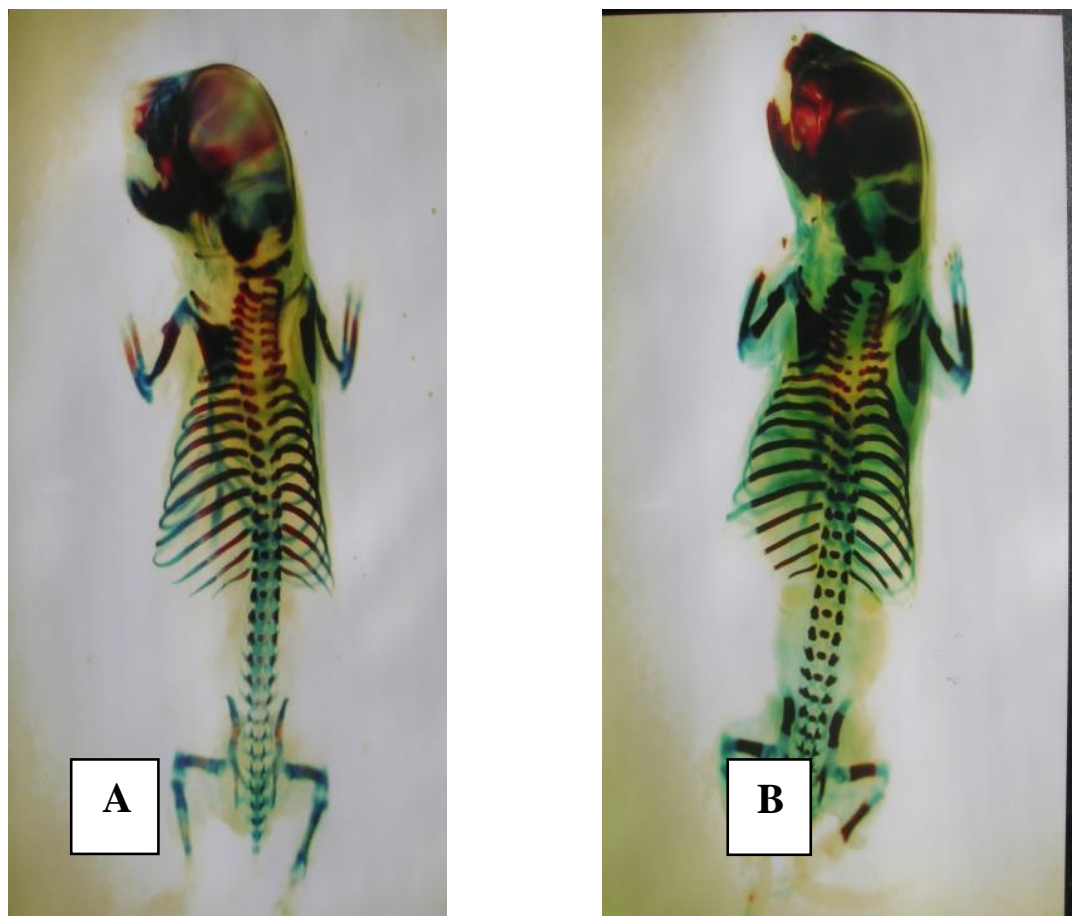

Fig(4): Two photographs of skeletons of two full term NF fetuses: control(A) and treated by $8 \mathrm{mg} / \mathrm{kg}$ of FX from $7-14 \mathrm{~d}$ of gestation (B) showing defective ossification in skull bones, sacral, pelvic ,hind limbs bones as well as metacarpals and metatarsals in comparison to control . 


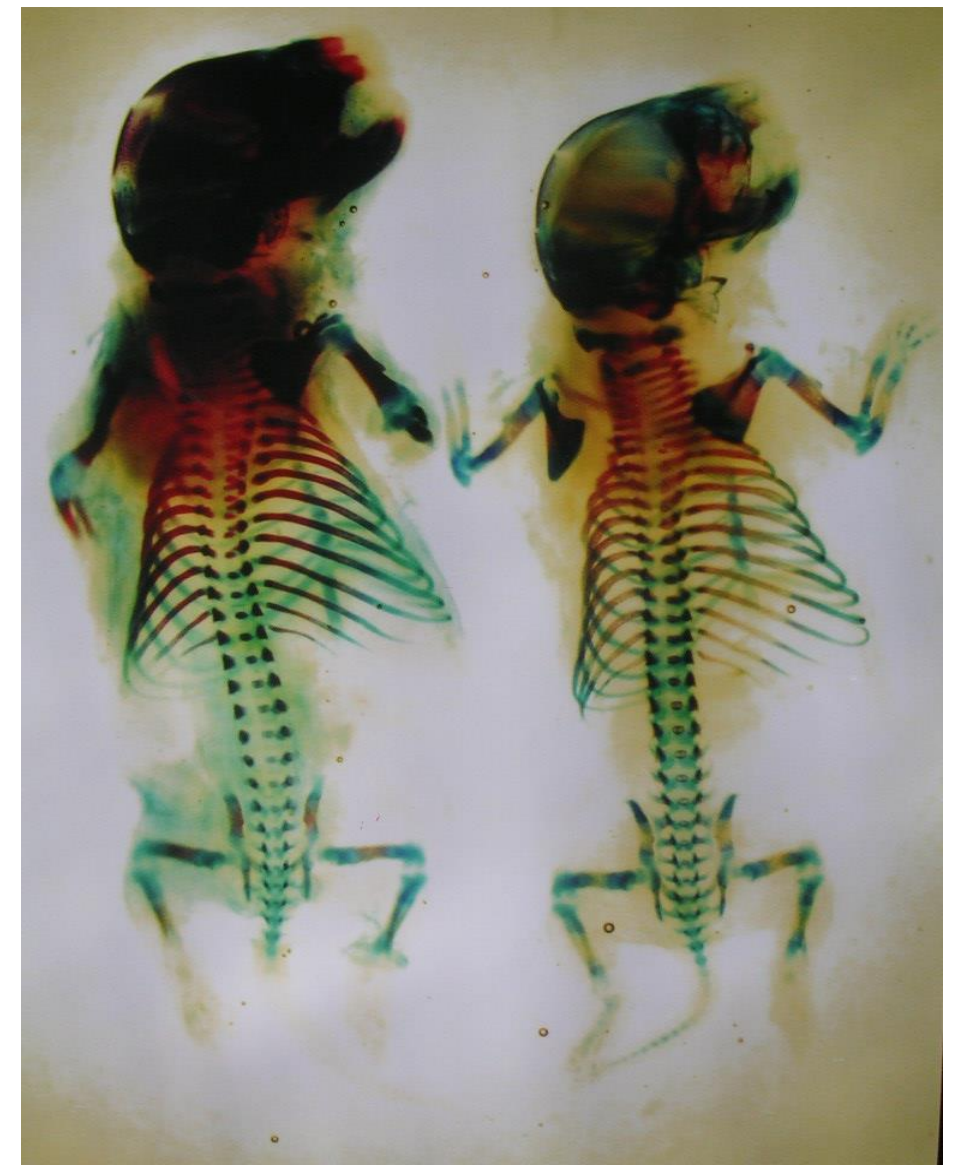

Fig (5): A photograph of dorsal aspects of two skeletons of full term PM fetuses treated by $8 / \mathrm{mg}$ of FX from 7-14 $\mathrm{d}$ of gestation showing that the fetuses have missed ossification of phalanges fore and hind limbs and lack of ossification in pelvic girdles and ribs. 
Table (1): Effects of oral administration of fluoxetine on the outcome of pregnancy and fetuses in normally fed and protein malnourished groups

\begin{tabular}{|c|c|c|c|c|c|c|c|c|c|c|c|}
\hline \multirow{2}{*}{ Groups } & \multirow{2}{*}{ 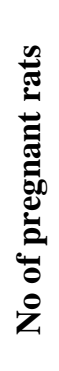 } & \multicolumn{2}{|c|}{ Abortion } & \multirow{2}{*}{$\begin{array}{c}\text { No } \\
\text { of } \\
\text { mot } \\
\text { hers }\end{array}$} & \multicolumn{2}{|c|}{$\begin{array}{r}\text { Total } \\
\text { implant. }\end{array}$} & \multirow{2}{*}{$\begin{array}{l}\text { No of } \\
\text { alive } \\
\text { fetus }\end{array}$} & \multicolumn{2}{|c|}{ Resorption } & \multicolumn{2}{|c|}{$\begin{array}{c}\text { External } \\
\text { anomalies } \\
\text { (hematoma) }\end{array}$} \\
\hline & & No & $\%$ & & No & $\begin{array}{r}\text { /moth } \\
\text { er }\end{array}$ & & No & $\%$ & No & $\%$ \\
\hline $\begin{array}{l}\text { NF Control } \\
\text { (C1) }\end{array}$ & 10 & 1 & 10 & 9 & 62 & 6.9 & 60 & 2 & 3.2 & - & - \\
\hline $\begin{array}{l}\text { FX(2mg7-14 } \\
\text { d)(E1) }\end{array}$ & 10 & 3 & 30 & 7 & 47 & 6.7 & 45 & 2 & 4.3 & 21 & 14.7 \\
\hline $\begin{array}{l}\text { FX(2mg15-20 } \\
\text { d)(E2) }\end{array}$ & 14 & 2 & 14.2 & 12 & 54 & 4.5 & 52 & 2 & 3.7 & 22 & 42.3 \\
\hline $\begin{array}{l}\text { FX(8mg7-14 } \\
\text { d)(E3) }\end{array}$ & 14 & 6 & 42.9 & 8 & 44 & 5.5 & 42 & 2 & 4.6 & 14 & 33.3 \\
\hline $\begin{array}{l}\text { FX }(8 m g 15-20 \\
\text { d)(E4) }\end{array}$ & 14 & 6 & 42.9 & 8 & 52 & 6.5 & 52 & 2 & 3.8 & 36 & 72 \\
\hline $\begin{array}{l}\text { PM Control } \\
\text { (C2) }\end{array}$ & 10 & 2 & 20 & 8 & 39 & 4.8 & 37 & 2 & 5.4 & 7 & 18.9 \\
\hline $\begin{array}{l}\text { FX(2mg7-14 } \\
\text { d)(E5) }\end{array}$ & 12 & 4 & 33.3 & 8 & 48 & 6 & 45 & 3 & 6.3 & 18 & 40 \\
\hline $\begin{array}{l}\text { FX }(2 m g 15-20 \\
\text { d)(E6) }\end{array}$ & 12 & 4 & 33.3 & 8 & 52 & 6.5 & 48 & 4 & 7.7 & 30 & 62.5 \\
\hline $\begin{array}{l}\text { FX(8mg7-14 } \\
\text { d)(E7) }\end{array}$ & 14 & 7 & 50 & 7 & 35 & 5 & 30 & 5 & 14.3 & 13 & 43.3 \\
\hline $\begin{array}{l}\text { FX(8mg15-20 } \\
\text { d)(E8) }\end{array}$ & 12 & 5 & 41.6 & 7 & 36 & 5.1 & 32 & 4 & 11.1 & 7 & 21.9 \\
\hline
\end{tabular}


Table (2): Changes in fetal body weights; fetal crown -length and tail length induced byfluoxetine in normally fed (NF) and protein malnourished (PM) rats.

\begin{tabular}{|c|c|c|c|c|c|c|c|c|}
\hline \multirow[t]{2}{*}{ Drug } & \multicolumn{2}{|c|}{$\begin{array}{l}\text { fetal body } \\
\text { weights } \\
\text { (g) }\end{array}$} & \multicolumn{2}{|c|}{$\begin{array}{l}\text { fetal crown - } \\
\text { length } \\
\text { (cm) }\end{array}$} & \multicolumn{2}{|c|}{$\begin{array}{c}\text { fetal tail } \\
\text { length }(\mathrm{cm})\end{array}$} & \multicolumn{2}{|c|}{$\begin{array}{l}\text { placental } \\
\text { weight } \\
\text { (g) }\end{array}$} \\
\hline & Mean & $\pm \mathrm{SD}$ & Mean & $\pm \mathrm{SD}$ & Mean & $\pm \mathrm{SD}$ & Mean & $\pm \mathrm{SD}$ \\
\hline Control N. F. (C1) & 3.77 & 0.59 & 3.96 & 0.23 & 1.27 & 0.11 & 0.59 & 0.07 \\
\hline $\begin{array}{l}\text { Flx. 2mg/kg (at 7-14 days) } \\
\text { (E1) }\end{array}$ & 3.58 & 0.40 & 3.82 & 0.30 & 1.23 & 0.09 & 0.56 & 0.09 \\
\hline $\begin{array}{l}\text { Flx. 2mg/kg (at 15-20 days) } \\
\text { (E2) }\end{array}$ & 3.58 & 0.23 & 3.94 & 0.27 & 1.21 & 0.07 & 0.49 & 0.05 \\
\hline $\begin{array}{l}\text { Flx. 8mg/kg (at 7-14 days) } \\
\text { (E3) }\end{array}$ & 3.70 & 0.58 & 3.76 & 0.16 & 1.20 & 0.08 & 0.48 & 0.13 \\
\hline $\begin{array}{l}\text { Flx. 8mg/kg (at 15-20 } \\
\text { days) }(E 4)\end{array}$ & 3.73 & 0.66 & 3.69 & 0.21 & \begin{tabular}{|l|l|}
1.18 \\
\end{tabular} & $\mathbf{0 . 0 5}$ & 0.54 & 0.04 \\
\hline Control P. M. (C2) & 3.34 & 0.43 & $* * 2.39$ & 0.11 & 1.27 & 0.07 & 0.52 & 0.05 \\
\hline $\begin{array}{l}\text { Flx. 2mg/kg (at 7-14 days) } \\
\text { (E5) }\end{array}$ & $\mathbf{3 . 3 2}$ & 0.55 & $* * 2.34$ & 0.09 & 1.23 & 0.08 & 0.46 & 0.11 \\
\hline $\begin{array}{l}\text { Flx. 2mg/kg (at 15-20 days) } \\
\text { (E6) }\end{array}$ & 3.35 & 0.38 & $* * 2.26$ & 0.07 & 1.21 & 0.07 & 0.47 & 0.10 \\
\hline $\begin{array}{l}\text { Flx. 8mg/kg (at 7-14 days) } \\
\text { (E7) }\end{array}$ & $* 3.25$ & 0.34 & $* * 2.32$ & 0.08 & 1.20 & $\mathbf{0 . 1 0}$ & 0.49 & 0.10 \\
\hline $\begin{array}{l}\text { Flx. 8mg/kg (at 15-20 } \\
\text { days) }(\mathrm{E} 8)\end{array}$ & $* 3.09$ & 0.55 & $* * 2.26$ & 0.05 & 1.18 & 0.07 & 0.43 & 0.10 \\
\hline
\end{tabular}


Table (3): Effects of protein malnutrition and fluoxetine administration on hematological parameters of fetuses.

\begin{tabular}{|c|c|c|c|c|c|c|}
\hline \multirow[t]{2}{*}{ Drug } & 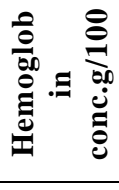 & 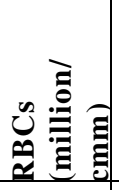 & 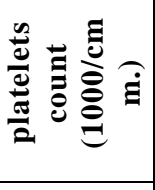 & 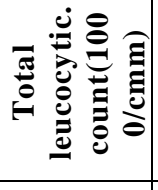 & 冚 & 莞 \\
\hline & 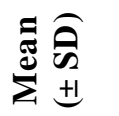 & 㿣 & 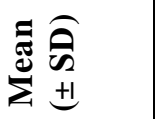 & 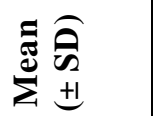 & 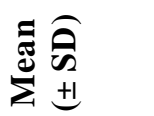 & 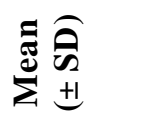 \\
\hline Control N. F. (C1) & $\begin{array}{l}14.9 \\
(1.8)\end{array}$ & $\begin{array}{c}7.83 \\
(1.43 \\
) \\
\end{array}$ & $\begin{array}{c}654 \\
(173)\end{array}$ & $\begin{array}{l}10.2 \\
(2.7)\end{array}$ & $\begin{array}{l}72.0 \\
(6.1)\end{array}$ & $\begin{array}{l}11.6 \\
(3.4)\end{array}$ \\
\hline $\begin{array}{l}\text { Flx. 2mg/kg (at 7-14 } \\
\text { days) (E1) }\end{array}$ & $\begin{array}{l}14.3 \\
(1.2)\end{array}$ & $\begin{array}{c}6.43 \\
(1.32 \\
)\end{array}$ & $\begin{array}{c}675 \\
(124)\end{array}$ & $\begin{array}{c}\mathbf{8 . 8} \\
(1.3)\end{array}$ & $\begin{array}{l}72.5 \\
(5.6)\end{array}$ & $\begin{array}{l}13.0 \\
(2.9)\end{array}$ \\
\hline $\begin{array}{l}\text { Flx. 2mg/kg (at 15- } \\
20 \text { days) (E2) }\end{array}$ & $\begin{array}{l}14.6 \\
(1.0)\end{array}$ & $\begin{array}{c}6.76 \\
(0.56 \\
)\end{array}$ & $\begin{array}{c}622 \\
(111)\end{array}$ & $\begin{array}{c}9.4 \\
(1.3)\end{array}$ & $\begin{array}{l}71.8 \\
(4.2)\end{array}$ & $\begin{array}{l}12.4 \\
(3.0)\end{array}$ \\
\hline $\begin{array}{l}\text { Flx. 8mg/kg (at 7-14 } \\
\text { days) }(\mathrm{E3})\end{array}$ & $\begin{array}{c}13 . \\
(1.0)\end{array}$ & $\begin{array}{c}5.73 \\
(1.25 \\
)\end{array}$ & $\begin{array}{c}535 \\
(139)\end{array}$ & $\begin{array}{l}11.5 \\
(3.6)\end{array}$ & $\begin{array}{l}86.6 \\
(7.5)\end{array}$ & $\begin{array}{c}9.0 \\
(5.4)\end{array}$ \\
\hline $\begin{array}{l}\text { Flx. 8mg/kg (at 15- } \\
20 \text { days) (E4) }\end{array}$ & $\begin{array}{l}14.0 \\
(0.8)\end{array}$ & $\begin{array}{c}6.98 \\
(0.46 \\
)\end{array}$ & $\begin{array}{c}477 \\
(110)\end{array}$ & $\begin{array}{l}18.5 \\
(4.2)\end{array}$ & $\begin{array}{c}80.7 \\
(18.6)\end{array}$ & $\begin{array}{c}7.2 \\
(3.5)\end{array}$ \\
\hline Control P. M. (C2) & $\begin{array}{l}11.4 \\
(0.8)\end{array}$ & $\begin{array}{c}5.20 \\
(0.67 \\
)\end{array}$ & $\begin{array}{c}435 \\
(131)\end{array}$ & $\begin{array}{l}12.4 \\
(4.4)\end{array}$ & $\begin{array}{l}81.3 \\
(7.2)\end{array}$ & $\begin{array}{c}9.2 \\
(4.1)\end{array}$ \\
\hline $\begin{array}{l}\text { Flx. 2mg/kg (at 7-14 } \\
\text { days) (E5) }\end{array}$ & $\begin{array}{l}10.8 \\
(1.4)\end{array}$ & $\begin{array}{c}3.94 \\
(0.47 \\
)\end{array}$ & $\begin{array}{c}457 \\
(124)\end{array}$ & $\begin{array}{l}14.9 \\
(3.0)\end{array}$ & $\begin{array}{l}81.1 \\
(4.7)\end{array}$ & $\begin{array}{l}11.6 \\
(3.4)\end{array}$ \\
\hline $\begin{array}{l}\text { Flx. 2mg/kg (at 15- } \\
20 \text { days) (E6) }\end{array}$ & $\begin{array}{l}10.6 \\
(2.0)\end{array}$ & $\begin{array}{c}4.39 \\
(0.51 \\
)\end{array}$ & $\begin{array}{c}408 \\
(133)\end{array}$ & $\begin{array}{l}16.2 \\
(5.3)\end{array}$ & $\begin{array}{l}78.4 \\
(8.5)\end{array}$ & $\begin{array}{l}12.4 \\
(3.8)\end{array}$ \\
\hline $\begin{array}{l}\text { Flx. 8mg/kg (at 7-14 } \\
\text { days) (E7) }\end{array}$ & $\begin{array}{c}9.6 \\
(1.9)\end{array}$ & $\begin{array}{c}3.82 \\
(0.34 \\
)\end{array}$ & $\begin{array}{c}406 \\
(113)\end{array}$ & $\begin{array}{l}20.7 \\
(4.9)\end{array}$ & $\begin{array}{l}88.5 \\
(3.2)\end{array}$ & $\begin{array}{c}6.9 \\
(2.4)\end{array}$ \\
\hline $\begin{array}{l}\text { Flx. 8mg/kg (at 15- } \\
20 \text { days) (E8) }\end{array}$ & $\begin{array}{l}10.2 \\
(0.8)\end{array}$ & $\begin{array}{c}3.62 \\
(0.42 \\
) \\
\end{array}$ & $\begin{array}{c}388 \\
(115)\end{array}$ & $\begin{array}{c}9.0 \\
(1.4)\end{array}$ & $\begin{array}{l}74.3 \\
(4.1)\end{array}$ & $\begin{array}{l}16.2 \\
(5.3)\end{array}$ \\
\hline
\end{tabular}

*significant $\mathrm{P}<0.01$

**highly significant $\mathrm{P}<0.001$ 
Table (4): Incidence of fetal skeletal malformations induced by fluoxetine in normally fed and protein malnourished rats

\begin{tabular}{|c|c|c|c|c|c|c|c|c|c|c|c|c|c|}
\hline \multirow[b]{3}{*}{ Groups } & \multirow[b]{3}{*}{$\begin{array}{l}\text { No. of } \\
\text { alive } \\
\text { fetuse } \\
\text { S }\end{array}$} & \multicolumn{12}{|c|}{ Abnormalities\% } \\
\hline & & \multirow{2}{*}{ 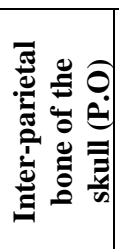 } & \multirow{2}{*}{ 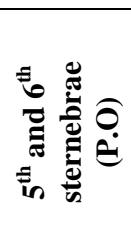 } & \multicolumn{4}{|c|}{ Forelimbs bones } & \multicolumn{6}{|c|}{ Hind limbs bones } \\
\hline & & & & 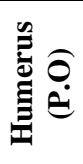 & 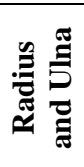 & 突 & 总 & 烂引 & $\stackrel{\frac{0}{3}}{\vec{E}}$ & 氖 & 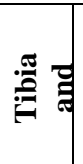 & 莺 & 总 \\
\hline $\begin{array}{l}\text { NF Control } \\
\text { (C1) }\end{array}$ & 60 & - & - & - & - & - & - & - & & - & - & - & - \\
\hline $\begin{array}{c}\text { FX(2mg7-14 } \\
\text { d)(E1) }\end{array}$ & 45 & 70 & 70 & 30 & 30 & 30 & 90 & 50 & 50 & 60 & 60 & 70 & 60 \\
\hline $\begin{array}{c}\text { FX(2mg15-20 } \\
\text { d)(E2) }\end{array}$ & 52 & 50 & 50 & 10 & 10 & 10 & 90 & 30 & 30 & 50 & 50 & 40 & 60 \\
\hline $\begin{array}{c}\text { FX(8mg7-14 } \\
\text { d)(E3) }\end{array}$ & 42 & 60 & 80 & - & - & - & 60 & 60 & 60 & 80 & 80 & 60 & 10 \\
\hline $\begin{array}{c}\text { FX(8mg15-20 } \\
\text { d)(E4) }\end{array}$ & 52 & 30 & 30 & - & - & 20 & 90 & 40 & 40 & 70 & 70 & 80 & 10 \\
\hline $\begin{array}{l}\text { PM Control } \\
\text { (C2) }\end{array}$ & 37 & 10 & 30 & - & 10 & - & 80 & - & - & 10 & 10 & 20 & 50 \\
\hline $\begin{array}{c}\text { FX(2mg7-14 } \\
\text { d)(E5) }\end{array}$ & 45 & - & - & - & - & - & 60 & - & - & - & - & - & 20 \\
\hline $\begin{array}{c}\text { FX(2mg15-20 } \\
\text { d)(E6) }\end{array}$ & 48 & - & - & - & - & - & 70 & 10 & 10 & 10 & 10 & - & 40 \\
\hline $\begin{array}{c}\text { FX(8mg7-14 } \\
\text { d)(E7) }\end{array}$ & 30 & 80 & 80 & 50 & 50 & 80 & 10 & 90 & 90 & 90 & 90 & 100 & 100 \\
\hline $\begin{array}{c}\text { FX }(8 m g 15-20 \\
\text { d)(E8) }\end{array}$ & 32 & - & - & - & - & - & 80 & - & - & - & - & 10 & 70 \\
\hline
\end{tabular}

M.O: denotes miss ossified percentage (\%)
P.O: denotes partially ossified

The data represented as 


\section{Discussion}

Since the pioneering work of Eward et al. (1914) demonstrating that maternal dietary protein deficiency resulted in lower birth weights and decreased vigor of the offspring in pigs, there have been extensive studies of the effects of dietary protein restriction on fetal growth in humans, pigs and rats

( Pond et al., 1992; Schoknecht et al., 1994; Jain et al., 1995; Desai et al. ,1996). Collectively, these studies have shown that protein deficiency during early or mid-gestation results in decreased placental and fetal growth and may permanently retard postnatal growth.

Amino acids are not only the building blocks of proteins and peptides, but also essential precursors for the synthesis of important molecules such as hormones, neurotransmitters, purine and pyrimidine nucleotides, polyamines, creatine, carni-tine, nitric oxide (NO) (Moncada and Higgs ,1993) and porphyrins (Reeds and Hutchens, 1994). NO synthesized from arginine by NO synthase, was reported to be essential for fertilization (Herrero et al 1996), embryo attachment and development in the uterus (Norman 1996,Novaro et al. 1997) and plays a critical role in regulating uterine blood flow and thus nutrient supply to the fetus during gestation (Sladek et al. 1997).

In this study the percentage of resorptions in normally fed control group was $3.2 \%$ while in the protein malnourished one it was $5.4 \%$.

The mean body weight of control normally fed group was $3.77 \pm 0.59 \mathrm{~g}$ while in protein malnourished control group it was $3.34 \pm 0.43 \mathrm{~g}$. Mean fetal crown- rump length and fetal tail length were significantly decreased in control malnourished group compared to normally feed one.

Mean placental weight was significantly reduced in control malnourished group. Levy and Jackson (1993) reported a decrease in the number of viable fetuses and an increase in the number of resorptions in pregnant rats feeding $6 \%$ and $9 \%$ protein diet. The placental weight was not different to the $18 \%$ group and on the $12 \%$ diet, but was significantly inc-reased on the $9 \%$ diet and significantly decreased on the $6 \%$ diet. Fetal weight was greatest on the $12 \%$ diet and significantly decreased on the $9 \%$ diet. The decrease in concentration of essential and non- essential amino acids in the fetus may be a mechanism whereby maternal protein restriction results in fetal growth retardation (Guayao et al. 1998). In the present study, fetuses of control malnourished group have missed ossific-ation of phalanges of fore and hind limbs in comparison to normal control. Some of these fetuses showed defective skull and vertebral cartilage formation. According to Miwa et al. (1990) prenatal protein malnutrition may delay the changes of proteoglycan character, which could affect the mineralization of fetal bones.

In this study $\mathrm{Hb}$ level and $\mathrm{RBCs}$ count were significantly lower in protein malnourished control group in comparison to fetuses of control normal group. Total leucocytic count was higher in fetuses of malnourished control group in comparison to fetuses of normally nourished control group. The increase of total leucocytic count was associated with an increase in the lymphocytes $\%$ and proportional decrease in the neutrophils \%. Maternal protein malnutrition is a regulatory factor in fetal mineral homeostasis. Maternal low protein diet may affect transport of iron across the placenta leading to anaemia (Barone $\boldsymbol{e t}$ al.,1998). Amino acids are essential precursors for the synthesis of porphyrins (Reeds and Hutchens, 1994). Decrease in amino acid content of maternal diet may lead to decrease in synthesis of hemoglobin (Cosens et al., 1977). Increased total leucocytic count and lymphocytes \% may be due to immaturity of the fetus as a result of maternal malnutrition (Davies et al., 1992).

The present work showed that admini-stration of fluoxetine (FX)to normally fed pregnant rats during the period of organogenesis ( $7-14$ days) and the last week of gestational period $(15-20$ days) resulted in increased incidence of abortion compared to normal control pregnant rats. This increase was dose-dependent. This agrees with Koren et al., (2005) who demonstrated that antidepressants used by pregnant women may be associated with increased risk for spontaneous abortion. Also, Fluoxetine and its metabolites were found to traverse the placenta and distribute within the conceptus during periods of organogenesis and post organogenesis in Wistar rats (Pohland et al., 1989).

In the present study, increased percentage of resorbed fetuses was observed specially in normally fed rats treated with $8 \mathrm{mg} / \mathrm{kg}$ accordance with Carey and Mclaughlin fluoxetine during organogenesis period. This was in (2002), who observed prevalence of stillborn pups and pups with reduced birth weight and decreased viability in rats exposed to $\geq 1.5$ times the maximum recommended dose of fluoxetine in human.

In the present study, although fetal body weight was not significantly affected by time of administration or by doubling the dose of fluoxetine, one must be careful to evaluate the data in light of other known factor influencing this parameter. For instance, fetal weight is 
inversely proportional to litter size in mice, rats and rabbits (Hafez, 1963; McLaren, 1965).

In our study Fluoxetine resulted in significant reduction of FCRL and tail lengths when administrated to normally fed rats, in a dose of 8 $\mathrm{mg} / \mathrm{kg}$ during late gestational period.

Different doses of fluoxetine $(2,5,12.5 \mathrm{mg} /$ $\mathrm{kg}$ ) were given orally to pregnant rats by Byrd and Markham (1994). Maternal toxicity was observed only, at dose of $12.5 \mathrm{mg} / \mathrm{kg}$ by reduction of weight gain and food consumption. The authors added that fetal viability, weight and morphology were not affected by smaller doses. This was confirmed by Vorhees et al., (1994), who reported that giving a dose of 12.5 $\mathrm{mg} / \mathrm{kg}$ fluoxetine resulted in obvious loss of maternal weight, reduced litter sizes at birth and increased neonatal mortality.

Chambers et al. (1996) demonstrated an increased risk of premature birth and lower birth weight when fluoxetine was given to pregnant women during the last trimester compared to the first trimester. Fluoxetine (FX) is a selective serotonin reuptake inhibitor (SSRI) which increases serotonin neurotransmission. Serotonin is involved in the regulation of a variety of physiological systems, including the sleep wake cycle, circadian rhythms and the hypothalamic-pituitary-adrenal axis. Each of these systems plays also an important role in fetal development. FX causes an acute increase in plasma serotonin level, leading to a transient reduction in uterine blood flow. This, in turn, reduces the delivery of oxygen and nutrients to the fetus, thereby presenting a mechanism for reducing growth and / or eliciting preterm delivery. Moreover, because FX crosses the placenta, the fetus is exposed directly to $\mathrm{FX}$ as well as to the effects of the drug on the mother. (Morrison et al. 2005).

In the present work no major or minor fetal malformations were detected by external and internal examination of normally nourished fetuses exposed to different doses of fluoxetine in both gestational periods. These results were in agreement with the available animal and human experience with fluoxetine, which appeared to indicate that the antidepressant was not related to major congenital malformation (Pastuszak et al. 1993; Addis and Koren 2000).

In the present study dose-dependent hematomas were observed in normally fed (N.F) treated fetuses in comparison to control. In a study by Stanford and Patton (1992), higher frequency of skin hematomas were observed in rat fetuses subjected to fluoxetine $(5.6 \mathrm{mg} / \mathrm{kg} /$ day $)$ from day $7^{\text {th }}$ of gestation until delivery. The mechanism was thought to be related to the inhibition of serotonin uptake by platelets or vascular instability.

In the present study, skeletal examination of N.F fetuses maternally exposed to $2 \mathrm{mg}$ and $8 \mathrm{mg} / \mathrm{kg}$ of fluoxetine during both gestational periods revealed incomplete ossification of bones of skull, pelvis and hind limbs, moreover absence of small bones of fore and hind limbs. Daily administration of fluoxetine from $7^{\text {th }}$ to $14^{\text {th }}$ days of gestation had more influence on bone formation than late gestational period.

Shuey et al, (1992) mentioned that inhibition of 5-HT uptake into craniofacial epithelia of mouse embryo at 9-12 days of gestation might produce developmental defects by interference with serotonergic regulation of epithelialmesenchymal interactions important for normal cranio-facial morphogenesis. Skeletal changes induced by fluoxetine in the present work were in accordance with Warden et al, (2005) who studied the effects of fluox-etine on the growing skeleton in mice and found a reduction in bone formation without an increase in bone resorption and these effects were not influenced by serum biochemistries. They explained that fluox-etine might inhibit serotonin transporter, which was present on osteoclasts and played a critical role in the differentiation of these cells. Mundell (2004) reported that fluoxetine may stunt growing bone of mice.

\section{$\underline{\text { Reference }}$}

1- Addis A and Koren G (2000): Safety of fluoxetine during the first trimester of pregnancy: a Meta-analytical review of epidemiological studies. Psychol. Med., 1: $89-94$.

2- Anderson K E (1988): Influences of diet and nutrition on clinical pharmacokinetics. Clin pharmacokinet, 14: 325-346.

3- Anthony L E and Edozien J C (1975): Experimental protein and energy deficiencies in rat. J. Nutr., 105: 631-648.

4- Bamji MS and Sh arada D (1972): Hepatic glutathione reductase and riboflavin concentrations in experimental deficiency of thiamine and riboflavin in rats, J. Nutr., 102, 443-448.

5- Barker DJP (1994): The welcome Foundation Lecture, The fetal Origins of adult disease Proc. Roy. Soc. Lond, 262: 37-43.

6- Barone A; Harper $R$ and Wapnira RA (1998): Placental copper transport in the rat: interaction between copper and iron in maternal protein deficiency. Placenta, 19: 113-118.

7- Byrd $R$ and Markham J (1994): Developmental toxicology studies of Fluoxetine hydrochloride administeredv orally to rats and rabbits. Fund. Appl. Toxicol., 22: 511-518.

8- Carey C Mclaughlin MA (2002): Drugs in pregnancy and Lactation. hiladelphia :Lippincott 
Williams, wilkins (Eds).

9- Chambers CD; Johnson KA; Dick LM Felix R J and Lyons Jones K (1996): Birth outcomes in pregnant women taking fluoxetine. N. Engl. J. Med.,335: 1010-5.

10- Cosens G; Diamond I; Theriault LL and Hurley LS (1977) :Magnesium deficiency anemia in the rat fetus. Pediatr. Res. Jun; 11(6):758-64.

11- Cunningham FG; MacDonald P C; Gant NF; Levero KJ; Gilstrap LC; Hankins GDV and Clark SL (1997): Fetal growth restriction. In Williams Obstetrics, pp 839-853. eds FG cunningham, PC.

12- Davies NP; Buggins AG; Snijders RJ; Jenkins E; Layton DM and Nicolaides KH (1992): Blood leucocyte count in the human fetus. Arch. Dis. Child. April; 67(4 Spec No): 399-403.

13- Dawson B and Trapp GT (2001): Basic and Clinical Biostatistics, $3^{\text {rd }}$ edition, Lange medical book, Appleton \& Lange, Norwalk, Connecticut.

14- Day SM and Deheer DH (2001): Reversal of thedetrimental effects of chronic protein malnutrition on long bone fracture healing. J.orthop. Trauma. 15 (1) 47-53.

15- De onis M; Blossner $M$ and Villar J (1998): Levels of intrauterine growth retardation in developing countries. Eur.J. Clin. Nutr. 52-55S15.

16- Desai M; Crowther N J; Lucas A and Hales C N (1996): Organ-selective growth in the offspring of protein-restricted mothers. Br. J. Nutr.76: 591-603.

17- England JM; Ward SM and Down MC (1976):Microcytosis anisocytosis and the red cell indices in Iron deficiency. British. J.

Hematology, 34:589-594

18- Eward JM; Dox AW and Guernsey S C (1914): Theeffect of calcium, and protein fed pregnant swine upon the size, vigor, bone,coat and condition of the offspring. Am. J. Physio, ; 34:312-325

19- Guayao WU; Wilson G PondTroy OTT and Fuller, W Bazer (1998): Maternal dietary protein deficiency decreases amino acid concentrations in fetal plasma and allantoic fluid of pigs. Journal of Nutrition 128 (5): 894-902.

20- Hafez ESE (1963): Maternal influence on fetal size, int. J. fertile., (8): 547-553.

21- Hamed M R ; El-Assy YS; Issa AM and Raslan YA (1998) : Influence of protein malnutrition on paracetamol teratogenic potential In rats. 1- A Study on the incidence of gross anomalies. J. Egypt. Soc.Toxicol. 20 : 15 18.

22- Hamed M R; El Saied M E and Abdel Fatah A (1991): Influence of proteinmalnutrition on behavioral resp-onse to drugs in rat J.Drug Res. (Egypt) $20: 21$.

23- Hamed MR; El-Assy YS and Ezz-El-din E (1994): influence of protein maln-utrition on teratogenicity of acetylsalicylic acid in rats. Human and Experimental toxicology 13 (2): 8388.7-225.

24- Harding J E; (2001): The nutritional basis of the fetal origins of adult disease .Int $\mathrm{J}$ Epidemiol, $30: 15-23$.

25- Hayahoe FGJ and Flemans RJ ;(1982): A colour Atlas of Haematological cytology, $2^{\text {nd }}$ ed,Cambridge, U.S.A, 233: P240.

26- Herrero MB; Viggiano J M; Martinez S P and de Gimeno MF; (1996): Effects of nitric oxide synthase inhibitors on the outcome of in vitro fertilization in themouse. Reprod. Fertil.Dev. 8:301-304.

27- Jain SK; Shah M; Ransonet L; Wise R; Bocchini JA (1995): Maternal and neonatal plasma transthyretin (prealb-umin) concentrations and birth weight of newborn infants. Biol.Neonate, 68:10-14.

28- Koren G; Hemels M EH; Einarson A; Lanctot KL and Einarson TR (2005): Antidepressant use during pregnancy and the rates of spontaneous Abortion. A Meta analysis The Annals of pharmaco therapy 39: p. 803-809.

29- Kotera A and Madigan JE (1997): Manifestations of disease in the neonate in smith edition Large animal Eternal Medicine 2nd edition Mosby Company, Philadelphia.

30- Kramer MS (2002): Balanced Pro-tein/energy supplementation in pregn-ancy (cochraine Review) In the cochraine Library, Issues:CD 000032: update soft-ware, oxford.

31- LBWSE (2000): Low birth weight study in Egypt (1995 - 1997) Ministry of heath and population, heath mother child project in collaboration with USAID.

32- Levy L and Jackson AA (1993): Modest restriction of dietary protein during pregnancy in the rat fetal and placenta growth .J dev physiol $19(3): 113-8$.

33- Mansour E; Eissa A and Little G (1998): Screening of Cases admitted in 80 neonatal units in ministry of health hospitals during the period January 95 -June 96 .Egyptian J. Pediatric 15 $(1,2): 173-182$

34- McLaren A (1965):Genetic and Environmental effects on fetal and place-ntal growth in mice J.Reprod. Fertil (9)79- 98.

35- Mcleod MJ (1980): Defferential staining of cartilage and bone in whole mouse fetuses by Alcian blue and Alizarin red S. Teratology, 22: 255-301.

36- Miwa T; Shoji H; Solomonow M; Yazdani M and Nakamoto $T$ (1989): The effect of prenatal protein -energy malnutrition on collagen metabolism in fetal bones. Orthopedics, 12 (7): 973-7.

37- Miwa T; Shoji H; Solomonow $M$ and Nakamoto T (1990): The effects of prenatal protein - energy malnutrition on ossification of fetal rat bones: a biochemical study. Orthopedics, 13 (5): 541-8.

38- Moncada S and Higgs A (1993): The L-arginine-nitric oxide pathway. N. Engl. J. Med; 329:2002-2012.

39- Morrison JL; Riggs KW and Rurak D W (2005): Fluoxetine during pregnancy: impact on fetal development. J.Repro-duction, Fertility and Development, 17(16): 641-650.

40- Mundell E J (2004): Prozac May Stunt 
growing bones. Heath Day 8:40-55.

41-Norman J (1996) : Nitric oxide and the myometrium. Pharmacol. Ther. 70:91-100.

42- Nourbakhsh M; AL wood J G; Raccio J and Seligson D (1978): An evaluation of blood smears made by a new method using a spinner diluted blood. Am. J. clin. Path., 70: 885-888.

43- Novaro V; Gonzalez E; Jawerbaum A; Rettori V; Canteros G and Meno MF-(1997): Nitric oxide synthase regulation during embryonic implantation. Reprod.Fert.Dev:557564.

44- Pastuszak A; Schick-Boschetto B; Zuber C; Feldkamp M; Pinelli M; Sihn $S$ and et al (1993): Pregnancy outcome following first trimester exposure to fluoxetine (Prozac) . JAMA;269:2246-8.

45-Pohland RC; Byrd TK; Harmilton $M$ and koons J R (1989): Placental transfer and fetal distribution of fluoxetine in the rat .J pharm. 98(2) 198-205.

46-Pond WG; Maurer RR; Mersmann HJ and Cummins (1992): Response of fetal and newborn piglets to maternal protein restriction during early or late pregnancy. Growth Dev. Aging. 1992 56:115-127.

47- Reeds PJ and Hutchens T W (1994): Protein requirements: from nitrogen balance to functional impact. J. Nutr - 24:1754S-1764S.

48-Schoknecht PA; Newton G R; Weise DE and Pond WG (1994): Protein restriction in early pregnancy alters fetal and placental growth and allantoic fluid proteins in swine. Theriogenology 42:217-226.

49-Shuey DL; Sadler TW and Lauder JM (1992): Serotonin as a regulator of craniofacial morphogenesis site specific malformations following exposure to serotonin up take inhibitors. Teratology, 46: 367-378.

50-Sladek S M Magness $R$ R and Conrad K P (1997): Nitric oxide and pregnancy.Am. J. Physiol. 272:R441-R463.

51-Stanford $M$ and Patton J (1992): In utero exposure to fluoxetine HCI increases hematoma frequency at birth. Pharmacol Biochem Behav, 45: 959-62.

52- Taylor JD and Miler JDM (1965): A source of error in the cyanmethemoglobin method of determination ohaemoglobin concentration in blood containing carbon monoxide. Am. J. Clin. Pathol, 43:265.

53-Villar j; Menaldi M; Gulmezoglu M; Abalos E; Carrol G; kulier $R$ and de Onis $M$ (2003): Characteristics of randomized control trials included in systematic reviews of nutritional interventions reporting maternal morbidity mortality, preterm delivery, IUGR and small for gestational age and birth outcome. Nutr 133:1632s-1639s.

54-Vorhees CV; Acuff-Smith KD; Sch-illing MA and et al (1994): A developmental neurotoxicity evaluation of the effects of prenat exposure to fluoxetine in rats. Fundam Appl Toxico2:194-205.

55-Warden SJ; Robling AG; Sanders MS; Bliziotes $\mathrm{MM}$ and Turner $\mathrm{CH}$ (2005): Inhibition of the serotonin (5-hydroxytryptamine) transporter reduces bone accrual during growth. Endocrinology, 146 (2) 685-93.

56- Wertz R W and koepke JA (1977): A critical analysis of platelets counting method S. Am J. clin. Pathol., 68: 195-201 


\section{اثر نقص البروتين على سمية عقار القلوكستين

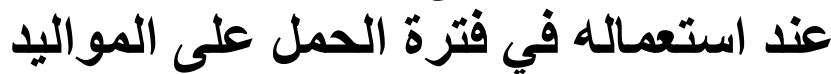

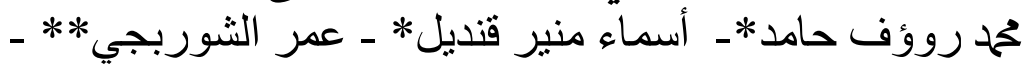

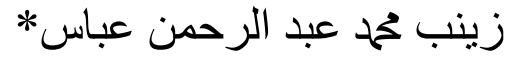

* هيئة الرقابة و البحوث الدو ائية**معهد الدراسات العليا للطفولة جامعة عين شمس

يمثل سوء التغذية البروتيني مشكلة اجتماعية فى أنحاء متفرقة من العالم وعلى وجه الخصوص الدول النامية. تهدف هذه الدراسة إلى معرفة مدى تأثير نقص البروتين فى الغذاء على قدرة عقار فلوكستين وهو من التحن

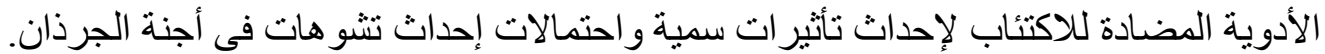

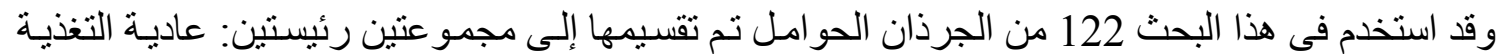

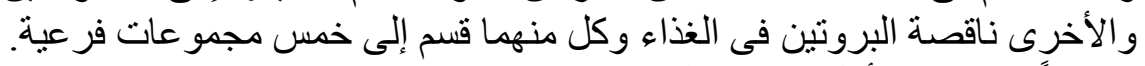

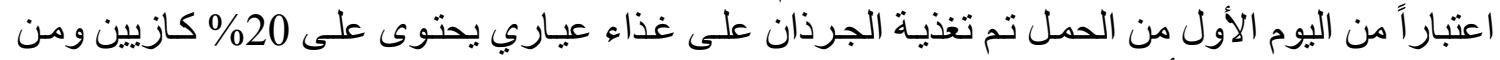

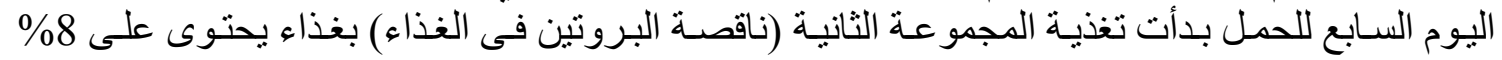

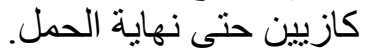

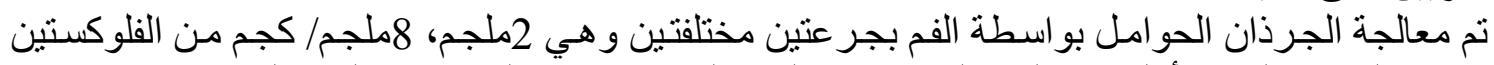

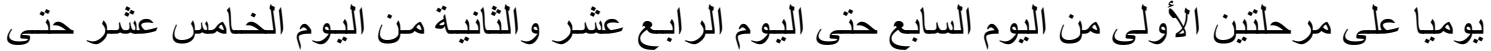

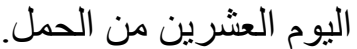
تم ذبح الإنات الحوامل فى اليوم الواحد و العشرين، وفى الحال تم إختبار الآتي: وزن المشيمة والأجنـة

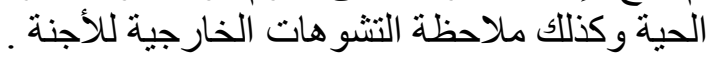

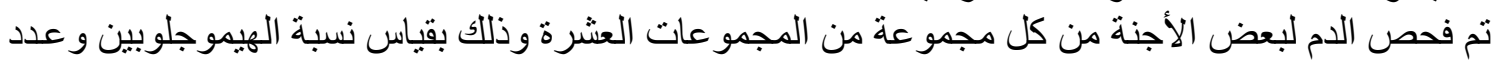
كرات الدم الحمر اء و البيضاء و الصفائح الدموية.

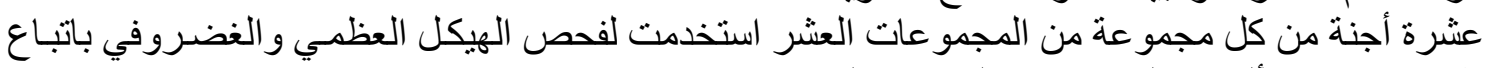

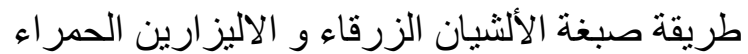
النتائج التي تم الحصول عليها من خلال الدر اسة كانت كالآتى :

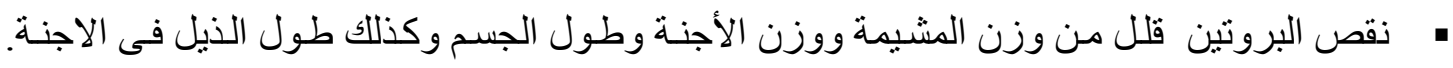
إعطاء الفلوكستين بالجر عة العالية 8 ملجم/ كجم أدى إلى نقص واضح الإنى فى طول

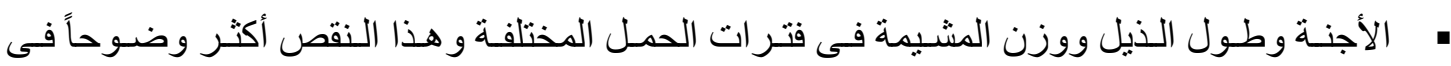
مجمو عات الجرذان ناقصة البروتين فى الغذاء.

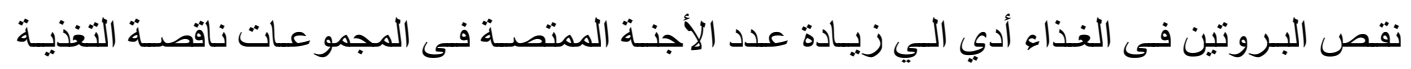

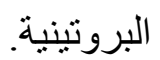
الفحص الظاهري للأجنة فى كل المجموعات سواء مجمو عات التغذية العادية أو مجموعات التغذية ناقصة البروتين أظهر بعض البقع الدموية فى الأطر اف بنسب مختلفة كما أظهر عدم وجود تثو هات

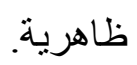
نقص البروتين فى غذاء الامهات الحوامل أدي الي خفض نسبة الهيموجلوبين وعدد كرات الدم

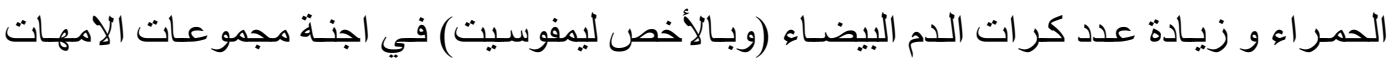
ناقصة التغذية البروتينية بالمقارنة بالمجموعات عيارية التغذية. عدد صفائح الدم قد نقص فى اجنة 
مجموعـات الامهـات ناقصـة التغذيـة البروتينيـة بالمقارنـة بالمجموعـات عياريـة التغذيـة 0 إعطـاء

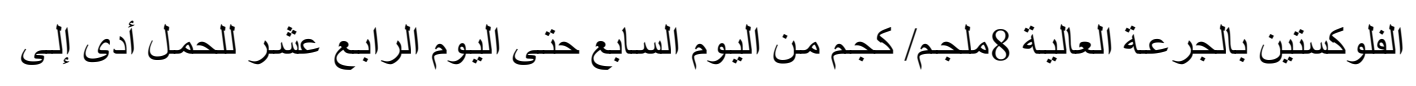

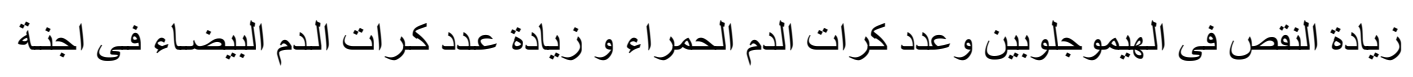
مجموعات الامهات ناقصة التغذية البروتينية و المجمو عات عيارية التغذية. فحص التر اكيب الهيكليـة للأجنـة أظهر زيـادة كبيرة فهى نشـوهات العظـام فى المجمو عـات ناقصسة التغذية البروتينية و عند اعطاء الفلوكستين من اليوم السـابع حتى اليوم الرابع عثر من الحمل وقد

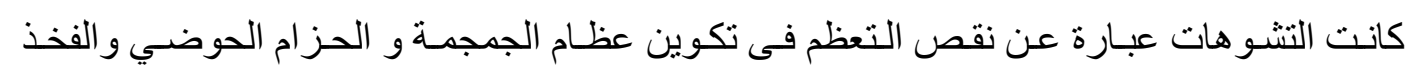
و عظام الساق و عظام هيكل القدم واليد. 